\title{
Molecular insights into colorectal cancer stem cell regulation by environmental factors
}

\author{
Daisuke Izumi ${ }^{1}$, Takatsugu Ishimoto ${ }^{1,2}$, Yasuo Sakamoto', Yuji Miyamoto', Hideo Baba1 \\ ${ }^{\prime}$ Department of Gastroenterological Surgery, Graduate School of Medical Science, Kumamoto University, 1-1-1 Honjo, Kumamoto 860-8556, Japan. \\ ${ }^{2}$ Cancer and Stem Cell Biology, Duke-NUS Graduate Medical School Singapore, 169857 Singapore.
}

Correspondence to: Dr. Takatsugu Ishimoto, Cancer and Stem Cell Biology, Duke-NUS Graduate Medical School, 8 College Road,

169857 Singapore. E-mail: taka1516@kumamoto-u.ac.jp

\section{A B S T R A C T}

Colorectal cancer remains a significant cause of cancer-related mortality worldwide, mainly because of tumor relapse and metastases. Cancer stem cells (CSCs) are considered to be the main cause of resistance to chemotherapeutic agents, as well as being responsible for distant metastases. Although CSCs themselves possess innate abilities for self-renewal and differentiation, the environment surrounding CSCs provides oxygen, nutrients and secreted factors, and also supports angiogenesis, thus it's responsible for maintaining their CSC properties. Furthermore, extensive investigations have revealed that obesity, accompanied by excess visceral adipose tissue, induces chronic inflammation, and is linked to the risk and progression of several gastrointestinal cancers, through modulating the capacities of the CSCs. This review presents the evidence linking colorectal CSCs and their environment and summarizes our current understanding of the molecular mechanisms underlying this relationship.

Key words: Cancer stem cells markers, colorectal cancer stem cell, nutrient, obesity, tumor microenvironment

\section{Introduction}

Colorectal cancer (CRC) is the fourth-leading cause of cancer-related deaths worldwide. ${ }^{[1]}$ Although the incidence of CRC has started to decline in developed countries, it continues to increase in developing countries. ${ }^{[2]}$ Environmental factors, including chronic inflammation, obesity, metabolism and nutrition, have become recognized as major contributors to the development of CRC. ${ }^{[3-6]}$ Dietary fat intake and obesity have been shown to be significantly involved in CRC progression through an increased risk of gene mutation, epigenomic alterations, and effects on the equilibrium of various adipokines. ${ }^{[7-11]}$ Chronic inflammation is also considered to be a risk factor for $\mathrm{CRC},{ }^{[6]}$ and inflammatory mediators and substances such as interleukin (IL)-6, tumor necrosis factor- $\alpha$ (TNF- $\alpha$ ), and reactive oxygen species have been shown to affect CRC development. ${ }^{[12-15]}$ The clearest link between chronic inflammation and CRC is seen in patients with inflammatory bowel disease, which has been reported to promote tumorigenesis by altering the microbial composition in the gut and supporting the expansion of microorganisms with genotoxic capabilities. ${ }^{[16]}$

Cancer stem cells (CSCs) are tumor cells that possess capabilities for self-renewal, clonal tumor

\begin{tabular}{|l|l|}
\hline \multicolumn{2}{|c|}{ Access this article online } \\
\hline Quick Response Code: & Website: \\
\hline & www.jcmtjournal.com \\
\cline { 2 - 2 } & \\
\hline
\end{tabular}

initiation and clonal long-term repopulation. ${ }^{[17,18]}$ The discovery of colorectal CSCs highlighted the existence of intratumoral heterogeneity, revealing the presence of tumor cells expressing markers characteristic of immature cells and with increased abilities to resist chemotherapy and to seed secondary tumors. ${ }^{[19-21]}$ CSCs were initially considered to be a cell population with well-defined phenotypic and molecular features. However, emerging evidence has revealed that certain cancer cells exhibit plasticity, and can change reversibly from stem to non-stem cells under the regulation of genetic, epigenetic and microenvironmental factors. ${ }^{[22-25]}$ In this review, we focused on accumulating new evidence indicating that microenvironmental factors maintained colorectal CSC properties responsible for promoting tumor development and metastasis.

\section{Markers for Colorectal CSCs}

CSCs have been isolated from cancer tissues using flow cytometry with specific surface markers. Several molecules have been proposed as colorectal

\footnotetext{
This is an open access article distributed under the terms of the Creative Commons Attribution-NonCommercial-ShareAlike 3.0 License, which allows others to remix, tweak, and build upon the work non-commercially, as long as the author is credited and the new creations are licensed under the identical terms.

For reprints contact: reprints@medknow.com

How to cite this article: Izumi D, Ishimoto T, Sakamoto Y, Miyamoto Y,
Bab H. Molecular insights into colorectal cancer stem cell regulation
by environmental factors. J Cancer Metastasis Treat 2015;1:156-62.
Received: $05-07-2015$; Accepted: $21-07-2015$.
}


CSC markers, including CD133, CD44, CD24, CD166, Lgr-5, and aldehyde dehydrogenase 1 (ALDH1) [Table 1]. ${ }^{[26]}$ CD133, a pentaspan transmembrane glycoprotein, ${ }^{[27]}$ was one of the first colorectal CSC markers to be identified. ${ }^{[19,20]}$ However, although selecting CRC cells based on AC133 positivity, an epitope of the CD133 protein identifies the tumorigenic and clonogenic population. ${ }^{[28]}$ CD133 expression has been detected throughout the normal gastrointestinal tract and is not restricted to the stem cell compartment. ${ }^{[29,30]}$ In addition, both CD133+ and CD133- metastatic CRC cells were able to form new tumors, suggesting that CD133 may not be a reliable marker of CSCs. ${ }^{[29]}$

The cell adhesion molecule CD44 has been identified as a cell surface marker associated with CSCs in several types of tumor. ${ }^{[31]} \mathrm{CD} 44+$ cells exhibited CSC properties, and a single cell could form a sphere in vitro, and a xenograft tumor resembling the original lesion in vitro. ${ }^{[32]}$ Overexpression of CD44 in CRC has been associated with depth of invasion and lymph node involvement and is shown to be an independent predictor of overall survival. ${ }^{[33]}$ Although CD44, like CD133, is not a specific marker for colorectal CSCs, it is possible that a combination of these two markers may be more reliable for detecting colorectal CSCs than either marker alone. ${ }^{[34]}$
In addition to cell surface markers, activities of certain pathways or enzymes may also act as markers of stemness. For instance, normal colorectal stem cells can be identified by the activity of ALDH1, a detoxifying enzyme that oxidizes intracellular aldehydes. ${ }^{[35,36]}$ ALDH1+ cells were sparse and restricted to the bottom of normal crypts, where stem cells reside but were increased in number and distributed further up the crypts during progression from normal epithelium to adenoma. ${ }^{[37]}$ In addition, implantation of ALDH1+ colon cancer cells into NOD/SCID mice generated xenograft tumors, whereas ALDH1- cells did not. ${ }^{[37]}$ These findings indicate that ALDH1 activity may be a useful colorectal CSC marker.

Other markers include CD166, epithelial cell adhesion molecule, CD29, CD24, CD26, Msi-1, Lgr-5, and Wnt activity/ $\beta$-catenin. ${ }^{[38-42]}$ The presence of these molecules has been associated with stemness characteristics both in vitro and in vivo. These markers were also used to enrich isolated CSCs further to enhance their tumorigenic ability. The transcription factors Oct-4 and Sox2 are also promising CSC markers, given their roles in cell renewal. Oct-4 and Sox2 levels have been shown to be elevated in CRC and to correlate with increased CSC proliferation and poor prognosis. ${ }^{[43,44]}$ Other pluripotency genes, Nanog, Lin-28, Klf-4, and c-myc, are regarded as promising surrogate markers, given that they appear to facilitate a shift towards an undifferentiated state. ${ }^{[45]}$

Table 1: CRC stem cell markers

\begin{tabular}{|c|c|c|c|}
\hline Marker & General function & Significance & References \\
\hline CD133 (Prominin-1) & $\begin{array}{l}\text { Pentaspan transmembrane } \\
\text { glycoprotein }\end{array}$ & $\begin{array}{l}\text { Tumor initiation in xenografts, colony formation, correlation } \\
\text { with: poor prognosis, survival, metastasis, resistance to } \\
\text { therapy }\end{array}$ & {$[28-31,41,43,4$} \\
\hline CD44 & $\begin{array}{l}\text { Cell adhesion molecule, } \\
\text { hyaluronic acid receptor }\end{array}$ & $\begin{array}{l}\text { Tumor initiation in xenografts, colony formation, association } \\
\text { with tumor stage, lymph node infiltration, survival }\end{array}$ & {$[32-36,41,4$} \\
\hline ALDH1- & Detoxifying enzyme & $\begin{array}{l}\text { Tumor initiation in xenografts, further enrichment, transition } \\
\text { from colitis to cancer, mitochondrial isoform is increased in } \\
\text { CRC }\end{array}$ & {$[37-39,41]$} \\
\hline CD166 (ALCAM) & Cell adhesion molecule & $\begin{array}{l}\text { Tumor initiation in xenografts, colony formation, further } \\
\text { enrichment, correlation with prognosis and survival }\end{array}$ & {$[41,45]$} \\
\hline EpCAM & Cell adhesion molecule & Expression in CD133p or CD $44+$ cells & [41] \\
\hline CD29 ( $\beta 1$-integrin) & Receptor for ECM & $\begin{array}{l}\text { Colony formation elevated in CRC, association with tumor } \\
\text { stage }\end{array}$ & {$[41,45]$} \\
\hline $\mathrm{CD} 24$ & Cell adhesion molecule & $\begin{array}{l}\text { Clonogenic ability, multilineage potential, further } \\
\text { enrichment, correlation with invasiveness, differentiation, } \\
\text { and survival }\end{array}$ & {$[41,45]$} \\
\hline CD26 & Cell surface glycoprotein & Tumor initiation and metastasis formation in a mouse model & [43] \\
\hline Msi-1 & $\begin{array}{l}\text { Maintenance of the } \\
\text { undifferentiated state }\end{array}$ & $\begin{array}{l}\text { Expression in CD133+ cells and spheroid cultures, } \\
\text { association with tumor stage }\end{array}$ & [22] \\
\hline Lgr-5 & $\begin{array}{l}\text { Wnt target gene, crypt base } \\
\text { restriction }\end{array}$ & $\begin{array}{l}\text { Tumorigenicity, poor prognostic factor, metastasis } \\
\text { formation, adenoma development in APC knockout mice }\end{array}$ & {$[40-42,44,4$} \\
\hline $\begin{array}{l}\text { Wnt activity/ } \\
\text { b-catenin }\end{array}$ & $\begin{array}{l}\text { Maintenance and proliferation } \\
\text { of the SC reservoir }\end{array}$ & $\begin{array}{l}\text { Associated with clonogenicity and tumorigenicity, detection } \\
\text { of low stage CRC cases with high risk of relapse }\end{array}$ & {$[40424445$} \\
\hline $\begin{array}{l}\text { Oct-4, So } \times 2 \text {, Nanog, } \\
\text { Lin-28, Klf-4, c-Myc }\end{array}$ & Transcription factors & $\begin{array}{l}\text { Correlation with poor prognosis, relapse, distant recurrence, } \\
\text { resistance to therapy }\end{array}$ & [46-48] \\
\hline
\end{tabular}

ALDH-1: Aldehyde dehydrogenase-1; CRC: Colorectal cancer; ALCAM: Activated leukocyte cell adhesion molecule; EpCAM: Epithelial cell adhesion molecule; ECM: Extracellular matrix; Lgr-5: Leucine-rich repeat containing G protein-coupled receptor 5; Msi-1: Musashi-1; SC: Stem cell; APS: Adenomatous polyposis coli 


\section{Colorectal CSCs Niche in the Tumor Microenvironment}

Tissue stem cells reside in their surrounding microenvironment, known as the stem cell niche, and play an essential role in maintaining tissue homeostasis through their abilities of self-renewal and differentiation. ${ }^{[46,47]}$ Lgr5+ stem cells in the intestinal crypts are interspersed among terminally differentiated Paneth cells, which act as guardians of the stem cells by providing essential niche signals. ${ }^{[48]}$ The tumor microenvironment surrounding cancer cells contains multiple cell types including immune cells, endothelial cells, and fibroblasts, in addition to the extracellular matrix. Recent evidence suggests that cancer cells interact with their microenvironment and each other by secreting growth factors, cytokines, and proteases. Furthermore, the properties of the CSCs depend on the CSC niche, which regulates their proliferation and differentiation, as well as those of the tissue stem cells.

Mesenchymal stem cells (MSCs) have been shown to be recruited into the tumor stroma, and to enhance tumor growth and metastasis in CRC. ${ }^{[49]}$ MSCs are considered as potential precursors of carcinoma-associated fibroblasts (CAFs, also known as tumor-associated fibroblasts), which play a key role in tumor progression in various types of cancer, including CRC..$^{[50-52]}$ Carcinoma-cell-derived IL-1 was shown to induce prostaglandin E2 (PGE2) secretion by MSCs, and the resulting PGE2 then acted in an autocrine manner with ongoing paracrine IL-1 signaling to induce expression of cytokines by the MSC, thus creating a CSC niche. ${ }^{[53]} \mathrm{A}$ recent study demonstrated that CRC cells can induce adjoining bone-marrow-derived MSCs to exhibit the typical characteristics of CAFs in vitro, and activated Notch signaling mediates transformation of bone-marrow-derived MSCs to CAFs through the downstream TGF- $\beta$ /Smad signaling pathway. ${ }^{[54]}$ Cytokines secreted by CAFs, including hepatocyte growth factor, osteopontin, and stromal-derived factor $1 \alpha$, increase CD44v6 expression in colorectal CRCs, which in turn promote migration and metastasis. ${ }^{[55]}$ Another study demonstrated that CSCs were resistant to conventional chemotherapy and that chemoresistance was also increased by CAFs. In this study, chemotherapy-treated human CAFs promoted CSC self-renewal and in vivo tumor growth associated with secretion of cytokines and chemokines, including IL-17A. ${ }^{[56]}$

The Wnt/ $\beta$-catenin signaling pathway has been shown to play critical roles during the transition from normal colorectal mucosa to adenocarcinoma. ${ }^{[57-59]}$ The tumor microenvironment may play a central role in malignant transformation by locally modifying $\beta$-catenin activity in tumor cells, thus contributing to tumor growth and cancer stemness. ${ }^{[60]}$ Likewise, myofibroblast-secreted factors, especially hepatocyte growth factor, activated Wnt signaling and restored the CSC phenotype in more differentiated tumor cells both in vitro and in vivo. ${ }^{[61]}$
Several studies have reported that CSCs reside in perivascular niches in certain types of cancer. ${ }^{[62-64]}$ Endothelial-cell-derived, soluble Jagged-1 led to Notch activation in colorectal CSC cells in a paracrine manner, thus promoting the CSC phenotype. ${ }^{[65]}$

Hypoxia is known to play pivotal roles in cell survival, angiogenesis, tumor invasion and metastasis, and is involved in the maintenance of self-renewal and the undifferentiated state of CSCs in various types of tumors. ${ }^{[66-68]}$ According to a study of colorectal cell line-derived CSCs, hypoxia maintained their stem-like phenotype and prevented differentiation of enterocytes and goblet cells by regulating CDX1 and Notch1. ${ }^{[69]}$

\section{Obesity, Nutrients, and Colorectal CSCs Properties}

Obesity and visceral adiposity are closely related to disorders such as diabetes, cardiovascular disease, and increased risk of various cancers, including CRC. ${ }^{[4,70,71]}$ Although a meta-analysis showed that an increase in the body mass index in men was associated with a relative CRC risk of 1.24, ${ }^{[72]}$ the relationship between increased body mass index and CRC risk in women is inconsistent. It is possible that the insulin and the insulin-like growth factor-1 axis may play different roles in colorectal carcinogenesis in men and women. ${ }^{[4,73]}$

Visceral obesity is associated with increased infiltration of inflammatory cells such as macrophages and T-cells into the adipose tissue, together with low-grade inflammation. ${ }^{[74-77]}$ Adipose tissues produce various growth factors, hormones, and cytokines known as adipocytokines, including leptin, resistin, visfatin, adiponectin, and numerous inflammatory mediators such as TNF- $\alpha$, IL-6, IL-8, IL-10, and IL-1 receptor agonists. These adipose-derived factors have demonstrated an intimate involvement in increased risk of CRC. ${ }^{[4]}$ In addition to adipocytokine-mediated inflammation, dyslipidemia, insulin resistance, and activation of the renin-angiotensin system may also contribute to CRC development. ${ }^{[78]}$

Colorectal CSC clones have been reported to express leptin receptors and to respond to leptin by cell proliferation, activation of the ERK $1 / 2$ and PI3K/AKT signaling pathways, enhanced growth in soft agar, and improved sphere formation associated with E-cadherin overexpression. Moreover, leptin counteracted the cytotoxic effects of 5-fluorouracil.[79] Other authors reported that leptin acted as a growth factor for carcinogen-induced colorectal tumors in a mouse model of obesity. They also showed that leptin receptor expression levels were markedly increased in colorectal tumors compared with normal epithelium, in association with activation of Wnt signaling. ${ }^{[8]}$

Chronic inflammation is considered to be a risk factor for $\mathrm{CRC}$, and an obvious association has been demonstrated between the incidence of CRC and inflammatory 
bowel diseases, such as ulcerative colitis and Crohn's disease. ${ }^{\left[{ }^{81,82]}\right.}$ A recent study showed that the inflammatory lipid mediators leukotriene D4 and PGE2 increased the ALDH+ cell population, colony formation capacity, and tumor growth in a xenograft model of colon cancer. ${ }^{[83]}$

A high-fat diet can cause changes in the composition of the intestinal microbiota, and affect gut immune and inflammatory effectors implicated in intestinal tumorigenesis. ${ }^{[84-86]}$ In contrast, omega-3 polyunsaturated fatty acids (PUFAs) have shown substantial benefits in patients with the chronic inflammatory disease. In a placebo-controlled, randomized controlled trial, administration of omega-3 PUFAs decreased polyp number, size, and overall burden in patients with familial adenomatous polyposis. ${ }^{[87]}$ Omega-3 PUFAs were shown to inhibit proliferation and angiogenesis, and exert a pro-apoptotic effect in several in vitro models of CRC. ${ }^{[88-91]}$ One possible molecular mechanism involves the G-protein-coupled receptor 120, which functions as an omega-3 fatty acid receptor/sensor in pro-inflammatory macrophages and mature adipocytes and represses the production of TNF and IL-6, as well as macrophage-induced tissue inflammation. ${ }^{[92,93]}$ Furthermore, omega-3 PUFAs down-regulated the expression of CRC stem-like cell marker CD133, and up-regulated the colorectal epithelium differentiation markers cytokeratin 20 and mucin $2{ }^{\left[{ }^{[94]}\right.}$ A recent study revealed that the low-cytotoxic combination of eicosapentaenoic acid-free fatty acid, epigallocatechin-3-gallate, and grape-seed extract (GSE) inhibited mammalian target of rapamycin signaling and thus reduced cell proliferation and induced apoptosis in CRC cells. ${ }^{\left[{ }^{[5]}\right]}$ GSE pre-treatment of adipocytes decreased their growth-promoting effects on CRC cells. In addition, adipocyte-conditioned media collected after chronic and acute pre-treatment with GSE significantly reduced the chemotactic properties of adipocytes toward CRC cell invasion. Finally, GSE decreased the expression of CD44 and inhibited adipocyte-mediated pro-tumorigenic signals in CSC-enriched colonospheres. ${ }^{[96]}$ Overall, these findings indicate a close link between obesity and chronic inflammation, leading to CRC progression through enhanced colorectal CSC properties, whereas some nutrients decrease the expression of CSC markers and attenuate the properties of CSCs.

\section{Conclusion}

The microenvironment surrounding cancer cells forms the CSC niche, allowing them to give rise to a hierarchy of proliferative and differentiating cells. Targeting the innate pathways and molecules between colorectal CSCs and their environment may thus represent a promising therapeutic strategy, and may provide a complementary approach to conventional therapies that target the malignant cells themselves. Anti-tumorigenic agents related to nutrients in the microenvironment may have particular potential to eliminate the population of colorectal CSCs. Further understanding of the molecular mechanisms underlying the regulation of CSC properties by environmental factors may lead to the development of potential therapeutic targets for patients with CRC.

\section{Financial support and sponsorship}

Nil.

\section{Conflicts of interest}

There are no conflicts of interest.

\section{References}

1. Torre LA, Bray F, Siegel RL, Ferlay J, Lortet-Tieulent J, Jemal A. Global cancer statistics, 2012. CA Cancer J Clin 2015;65:87-108.

2. Stewart BW, Wild CP. World Cancer Report 2014. Geneva: World Health Organization; 2014.

3. Akin H, Tozun N. Diet, microbiota, and colorectal cancer. J Clin Gastroenterol 2014;48 Suppl 1:S67-9.

4. Bardou M, Barkun AN, Martel M. Obesity and colorectal cancer. Gut 2013;62:933-47.

5. Song L, Li Y, He B, Gong Y. Development of Small Molecules Targeting the Wnt Signaling Pathway in Cancer Stem Cells for the Treatment of Colorectal Cancer. Clin Colorectal Cancer 2015. doi: 10.1016/j.clcc.2015.02.001.

6. Terzic J, Grivennikov S, Karin E, Karin M. Inflammation and colon cancer. Gastroenterology 2010;138:2101-14.e5.

7. Li R, Grimm SA, Chrysovergis K, Kosak J, Wang X, Du Y, Burkholder A, Janardhan K, Mav D, Shah R, Eling TE, Wade PA. Obesity, rather than diet, drives epigenomic alterations in colonic epithelium resembling cancer progression. Cell Metab 2014;19:702-11.

8. Aleksandrova $\mathrm{K}$, Boeing $\mathrm{H}$, Jenab M, Bueno-de-Mesquita HB, Jansen E, van Duijnhoven FJ, Fedirko V, Rinaldi S, Romieu I, Riboli E, Romaguera D, Westphal S, Overvad K, Tjonneland A, Boutron-Ruault MC, Clavel-Chapelon F, Kaaks R, Lukanova A, Trichopoulou A, Lagiou P, Trichopoulos D, Agnoli C, Mattiello A, Saieva C, Vineis P, Tumino R, Peeters PH, Arguelles M, Bonet C, Sanchez MJ, Dorronsoro M, Huerta JM, Barricarte A, Palmqvist R, Hallmans G, Khaw KT, Wareham N, Allen NE, Crowe FL, Pischon T. Total and high-molecular weight adiponectin and risk of colorectal cancer: the European Prospective Investigation into Cancer and Nutrition Study. Carcinogenesis 2012;33:1211-8.

9. Wong HL, Koh WP, Probst-Hensch NM, Van den Berg D, $\mathrm{Yu}$ MC, Ingles SA. Insulin-like growth factor-1 promoter polymorphisms and colorectal cancer: a functional genomics approach. Gut 2008;57:1090-6.

10. Ochs-Balcom HM, Cicek MS, Thompson CL, Tucker TC, Elston RC, Plummer SJ, Casey G, Li L. Association of vitamin D receptor gene variants, adiposity and colon cancer. Carcinogenesis 2008;29:1788-93.

11. Brink M, Weijenberg MP, De Goeij AF, Schouten LJ, Koedijk FD, Roemen GM, Lentjes MH, De Bruine AP, Goldbohm RA, Van Den Brandt PA. Fat and K-ras mutations in sporadic colorectal cancer in The Netherlands Cohort Study. Carcinogenesis 2004;25:1619-28.

12. Guina T, Biasi F, Calfapietra S, Nano M, Poli G. Inflammatory and redox reactions in colorectal carcinogenesis. Ann N Y Acad Sci 2015;1340:95-103.

13. Yang X, Zhang F, Wang Y, Cai M, Wang Q, Guo Q, Li Z, $\mathrm{Hu}$ R. Oroxylin A inhibits colitis-associated carcinogenesis through modulating the IL-6/STAT3 signaling pathway. Inflamm Bowel Dis 2013;19:1990-2000. 
14. Ullman TA, Itzkowitz SH. Intestinal inflammation and cancer. Gastroenterology 2011;140:1807-16.

15. Li Y, de Haar C, Chen M, Deuring J, Gerrits MM, Smits R, Xia B, Kuipers EJ, van der Woude CJ. Disease-related expression of the IL6/STAT3/SOCS3 signalling pathway in ulcerative colitis and ulcerative colitis-related carcinogenesis. Gut 2010;59:227-35.

16. Arthur JC, Perez-Chanona E, Muhlbauer M, Tomkovich S, Uronis JM, Fan TJ, Campbell BJ, Abujamel T, Dogan B, Rogers AB, Rhodes JM, Stintzi A, Simpson KW, Hansen JJ, Keku TO, Fodor AA, Jobin C. Intestinal inflammation targets cancer-inducing activity of the microbiota. Science 2012;338:120-3.

17. Clarke MF, Dick JE, Dirks PB, Eaves CJ, Jamieson CH, Jones DL, Visvader J, Weissman IL, Wahl GM. Cancer stem cells - Perspectives on current status and future directions: AACR Workshop on cancer stem cells. Cancer Res 2006;66:9339-44.

18. Nguyen LV, Vanner R, Dirks P, Eaves CJ. Cancer stem cells: an evolving concept. Nat Rev Cancer 2012;12:133-43.

19. O'Brien CA, Pollett A, Gallinger S, Dick JE. A human colon cancer cell capable of initiating tumour growth in immunodeficient mice. Nature 2007;445:106-10.

20. Ricci-Vitiani L, Lombardi DG, Pilozzi E, Biffoni M, Todaro M, Peschle C, De Maria R. Identification and expansion of human colon-cancer-initiating cells. Nature 2007;445:111-5.

21. Todaro M, Alea MP, Di Stefano AB, Cammareri P, Vermeulen L, Iovino F, Tripodo C, Russo A, Gulotta G, Medema JP, Stassi G. Colon cancer stem cells dictate tumor growth and resist cell death by production of interleukin-4. Cell Stem Cell 2007;1:389-402.

22. Roesch A, Fukunaga-Kalabis M, Schmidt EC, Zabierowski SE, Brafford PA, Vultur A, Basu D, Gimotty P, Vogt T, Herlyn M. A temporarily distinct subpopulation of slow-cycling melanoma cells is required for continuous tumor growth. Cell 2010;141:583-94.

23. Kreso A, Dick JE. Evolution of the cancer stem cell model. Cell Stem Cell 2014;14:275-91.

24. Zeuner A, Todaro M, Stassi G, De Maria R. Colorectal cancer stem cells: from the crypt to the clinic. Cell Stem Cell 2014;15:692-705.

25. Chao $\mathrm{CH}$, Chang CC, Wu MJ, Ko HW, Wang D, Hung MC, Yang JY, Chang CJ. MicroRNA-205 signaling regulates mammary stem cell fate and tumorigenesis. J Clin Invest 2014; $124: 3093-106$.

26. Vaiopoulos AG, Kostakis ID, Koutsilieris M, Papavassiliou AG. Colorectal cancer stem cells. Stem Cells 2012;30:363-71

27. Papailiou J, Bramis KJ, Gazouli M, Theodoropoulos G. Stem cells in colon cancer. A new era in cancer theory begins. Int $J$ Colorectal Dis 2011;26:1-11.

28. Kemper K, Grandela C, Medema JP. Molecular identification and targeting of colorectal cancer stem cells. Oncotarget 2010;1:387-95.

29. Shmelkov SV, Butler JM, Hooper AT, Hormigo A, Kushner J Milde T, St Clair R, Baljevic M, White I, Jin DK, Chadburn A, Murphy AJ, Valenzuela DM, Gale NW, Thurston G, Yancopoulos GD, D'Angelica M, Kemeny N, Lyden D, Rafii S. CD133 expression is not restricted to stem cells, and both CD133+ and CD133- metastatic colon cancer cells initiate tumors. J Clin Invest 2008;118:2111-20.

30. Karbanova J, Missol-Kolka E, Fonseca AV, Lorra C, Janich P, Hollerova H, Jaszai J, Ehrmann J, Kolar Z, Liebers C, Arl S, Subrtova D, Freund D, Mokry J, Huttner WB, Corbeil D. The stem cell marker CD133 (Prominin-1) is expressed in various human glandular epithelia. $J$ Histochem Cytochem 2008;56:977-93.

31. Ishimoto $\mathrm{T}$, Nagano $\mathrm{O}$, Yae $\mathrm{T}$, Tamada $\mathrm{M}$, Motohara $\mathrm{T}$, Oshima H, Oshima M, Ikeda T, Asaba R, Yagi H, Masuko T, Shimizu T, Ishikawa T, Kai K, Takahashi E, Imamura Y, Baba Y, Ohmura M, Suematsu M, Baba H, Saya H. CD44 variant regulates redox status in cancer cells by stabilizing the $\mathrm{xCT}$ subunit of system xc(-) and thereby promotes tumor growth. Cancer Cell 2011;19:387-400.

32. Du L, Wang $\mathrm{H}$, He L, Zhang J, Ni B, Wang X, Jin H, Cahuzac N, Mehrpour M, Lu Y, Chen Q. CD44 is of functional importance for colorectal cancer stem cells. Clin Cancer Res 2008; 14:6751-60.

33. Huh JW, Kim HR, Kim YJ, Lee JH, Park YS, Cho SH, Joo JK. Expression of standard CD44 in human colorectal carcinoma: association with prognosis. Pathol Int 2009;59:241-6.

34. Haraguchi N, Ohkuma M, Sakashita H, Matsuzaki S, Tanaka F, Mimori K, Kamohara Y, Inoue H, Mori M. CD133+CD44+ population efficiently enriches colon cancer initiating cells. Ann Surg Oncol 2008;15:2927-33.

35. Carpentino JE, Hynes MJ, Appelman HD, Zheng T, Steindler DA, Scott EW, Huang EH. Aldehyde dehydrogenase-expressing colon stem cells contribute to tumorigenesis in the transition from colitis to cancer. Cancer Res 2009;69:8208-15.

36. Chen Y, Orlicky DJ, Matsumoto A, Singh S, Thompson DC, Vasiliou V. Aldehyde dehydrogenase 1B1 (ALDH1B1) is a potential biomarker for human colon cancer. Biochem Biophys Res Commun 2011;405:173-9.

37. Huang EH, Hynes MJ, Zhang T, Ginestier C, Dontu G, Appelman H, Fields JZ, Wicha MS, Boman BM. Aldehyde dehydrogenase 1 is a marker for normal and malignant human colonic stem cells (SC) and tracks SC overpopulation during colon tumorigenesis. Cancer Res 2009;69:3382-9.

38. Barker N, Ridgway RA, van Es JH, van de Wetering M, Begthel H, van den Born M, Danenberg E, Clarke AR, Sansom OJ, Clevers H. Crypt stem cells as the cells-of-origin of intestinal cancer. Nature 2009;457:608-11.

39. Dalerba P, Dylla SJ, Park IK, Liu R, Wang X, Cho RW, Hoey T, Gurney A, Huang EH, Simeone DM, Shelton AA, Parmiani G, Castelli C, Clarke MF. Phenotypic characterization of human colorectal cancer stem cells. Proc Natl Acad Sci USA 2007; 104:10158-63.

40. Pang R, Law WL, Chu AC, Poon JT, Lam CS, Chow AK, $\mathrm{Ng}$ L, Cheung LW, Lan XR, Lan HY, Tan VP, Yau TC, Poon RT, Wong BC. A subpopulation of CD26+ cancer stem cells with metastatic capacity in human colorectal cancer Cell Stem Cell 2010;6:603-15.

41. Sato T, Vries RG, Snippert HJ, van de Wetering M, Barker N, Stange DE, van Es JH, Abo A, Kujala P, Peters PJ, Clevers H Single Lgr5 stem cells build crypt-villus structures in vitro without a mesenchymal niche. Nature 2009;459:262-5.

42. Vermeulen L, Todaro M, de Sousa Mello F, Sprick MR, Kemper K, Perez Alea M, Richel DJ, Stassi G, Medema JP. Single-cell cloning of colon cancer stem cells reveals a multi-lineage differentiation capacity. Proc Natl Acad Sci U S A 2008;105:13427-32.

43. Chang CJ, Chien Y, Lu KH, Chang SC, Chou YC, Huang CS, Chang $\mathrm{CH}$, Chen $\mathrm{KH}$, Chang YL, Tseng LM, Song WS, Wang JJ, Lin JK, Huang PI, Lan YT. Oct4-related cytokine effects regulate tumorigenic properties of colorectal cancer cells. Biochem Biophys Res Commun 2011;415:245-51.

44. Liu K, Lin B, Zhao M, Yang X, Chen M, Gao A, Liu F, Que J, Lan X. The multiple roles for Sox2 in stem cell maintenance and tumorigenesis. Cell Signal 2013;25:1264-71. 
45. Saiki $\mathrm{Y}$, Ishimaru S, Mimori $\mathrm{K}$, Takatsuno $\mathrm{Y}$, Nagahara M, Ishii H, Yamada K, Mori M. Comprehensive analysis of the clinical significance of inducing pluripotent stemness-related gene expression in colorectal cancer cells. Ann Surg Oncol 2009;16:2638-44.

46. Schofield R. The relationship between the spleen colony-forming cell and the haemopoietic stem cell. Blood Cells 1978;4:7-25.

47. Moore KA, Lemischka IR. Stem cells and their niches. Science 2006;311:1880-5.

48. Sato T, van Es JH, Snippert HJ, Stange DE, Vries RG, van den Born M, Barker N, Shroyer NF, van de Wetering M, Clevers H. Paneth cells constitute the niche for Lgr5 stem cells in intestinal crypts. Nature 2011;469:415-8.

49. Shinagawa K, Kitadai Y, Tanaka M, Sumida T, Kodama M, Higashi Y, Tanaka S, Yasui W, Chayama K. Mesenchymal stem cells enhance growth and metastasis of colon cancer. Int $J$ Cancer 2010;127:2323-33.

50. Orimo A, Gupta PB, Sgroi DC, Arenzana-Seisdedos F, Delaunay T, Naeem R, Carey VJ, Richardson AL, Weinberg RA. Stromal fibroblasts present in invasive human breast carcinomas promote tumor growth and angiogenesis through elevated SDF-1/CXCL12 secretion. Cell 2005;121:335-48.

51. Quail DF, Joyce JA. Microenvironmental regulation of tumor progression and metastasis. Nat Med 2013;19:1423-37.

52. Shinagawa K, Kitadai Y, Tanaka M, Sumida T, Onoyama M, Ohnishi M, Ohara E, Higashi Y, Tanaka S, Yasui W, Chayama K. Stroma-directed imatinib therapy impairs the tumor-promoting effect of bone marrow-derived mesenchymal stem cells in an orthotopic transplantation model of colon cancer. Int J Cancer 2013;132:813-23.

53. Li HJ, Reinhardt F, Herschman HR, Weinberg RA. Cancer-stimulated mesenchymal stem cells create a carcinoma stem cell niche via prostaglandin E2 signaling. Cancer Discov 2012;2:840-55.

54. Peng Y, Li Z, Yang P, Newton IP, Ren H, Zhang L, Wu H, Li Z. Direct contacts with colon cancer cells regulate the differentiation of bone marrow mesenchymal stem cells into tumor associated fibroblasts. Biochem Biophys Res Commun 2014;451:68-73.

55. Todaro M, Gaggianesi M, Catalano V, Benfante A, Iovino F, Biffoni M, Apuzzo T, Sperduti I, Volpe S, Cocorullo G, Gulotta G, Dieli F, De Maria R, Stassi G. CD44v6 is a marker of constitutive and reprogrammed cancer stem cells driving colon cancer metastasis. Cell Stem Cell 2014;14:342-56.

56. Lotti F, Jarrar AM, Pai RK, Hitomi M, Lathia J, Mace A, Gantt GA Jr, Sukhdeo K, DeVecchio J, Vasanji A, Leahy P, Hjelmeland AB, Kalady MF, Rich JN. Chemotherapy activates cancer-associated fibroblasts to maintain colorectal cancer-initiating cells by IL-17A. $J$ Exp Med 2013;210:2851-72.

57. Bienz M, Clevers H. Linking colorectal cancer to Wnt signaling. Cell 2000;103:311-20.

58. Clevers $H$. Wnt/beta-catenin signaling in development and disease. Cell 2006;127:469-80.

59. Fearon ER, Vogelstein B. A genetic model for colorectal tumorigenesis. Cell 1990;61:759-67.

60. Le NH, Franken P, Fodde R. Tumour-stroma interactions in colorectal cancer: converging on beta-catenin activation and cancer stemness. Br J Cancer 2008;98:1886-93.

61. Vermeulen L, De Sousa EM, van der Heijden M, Cameron K, de Jong JH, Borovski T, Tuynman JB, Todaro M, Merz C, Rodermond H, Sprick MR, Kemper K, Richel DJ, Stassi G, Medema JP. Wnt activity defines colon cancer stem cells and is regulated by the microenvironment. Nat Cell Biol 2010;12:468-76.

62. Butler JM, Kobayashi H, Rafii S. Instructive role of the vascular niche in promoting tumour growth and tissue repair by angiocrine factors. Nat Rev Cancer 2010;10:138-46.

63. Calabrese C, Poppleton H, Kocak M, Hogg TL, Fuller C, Hamner B, Oh EY, Gaber MW, Finklestein D, Allen M, Frank A, Bayazitov IT, Zakharenko SS, Gajjar A, Davidoff A, Gilbertson RJ. A perivascular niche for brain tumor stem cells. Cancer Cell 2007;11:69-82.

64. Krishnamurthy S, Dong Z, Vodopyanov D, Imai A, Helman JI, Prince ME, Wicha MS, Nor JE. Endothelial cell-initiated signaling promotes the survival and self-renewal of cancer stem cells. Cancer Res 2010;70:9969-78.

65. Lu J, Ye X, Fan F, Xia L, Bhattacharya R, Bellister S, Tozzi F, Sceusi E, Zhou Y, Tachibana I, Maru DM, Hawke DH, Rak J, Mani SA, Zweidler-McKay P, Ellis LM. Endothelial cells promote the colorectal cancer stem cell phenotype through a soluble form of Jagged-1. Cancer Cell 2013;23:171-85.

66. Liang D, Ma Y, Liu J, Trope CG, Holm R, Nesland JM, Suo Z. The hypoxic microenvironment upgrades stem-like properties of ovarian cancer cells. BMC Cancer 2012;12:201.

67. Ma Y, Liang D, Liu J, Axcrona K, Kvalheim G, Stokke T, Nesland JM, Suo Z. Prostate cancer cell lines under hypoxia exhibit greater stem-like properties. PLoS One 2011;6:e29170.

68. Soeda A, Park M, Lee D, Mintz A, Androutsellis-Theotokis A, McKay RD, Engh J, Iwama T, Kunisada T, Kassam AB, Pollack IF, Park DM. Hypoxia promotes expansion of the CD133-positive glioma stem cells through activation of HIF-1alpha. Oncogene 2009;28:3949-59.

69. Yeung TM, Gandhi SC, Bodmer WF. Hypoxia and lineage specification of cell line-derived colorectal cancer stem cells. Proc Natl Acad Sci U S A 2011;108:4382-7.

70. Lovejoy JC, de la Bretonne JA, Klemperer M, Tulley R. Abdominal fat distribution and metabolic risk factors: effects of race. Metabolism 1996;45:1119-24.

71. Vongsuvanh R, George J, Qiao L, van der Poorten D. Visceral adiposity in gastrointestinal and hepatic carcinogenesis. Cancer Lett 2013;330:1-10.

72. Renehan AG, Tyson M, Egger M, Heller RF, Zwahlen M. Body-mass index and incidence of cancer: a systematic review and meta-analysis of prospective observational studies. Lancet 2008;371:569-78.

73. Yamaji T, Iwasaki M, Sasazuki S, Tsugane S. Gender difference in the association of insulin and the insulin-like growth factor axis with colorectal neoplasia. Int $J$ Obes (Lond) 2012;36:440-7.

74. Michaud A, Drolet R, Noel S, Paris G, Tchernof A. Visceral fat accumulation is an indicator of adipose tissue macrophage infiltration in women. Metabolism 2012;61:689-98.

75. Neels JG, Olefsky JM. Inflamed fat: what starts the fire? $J$ Clin Invest 2006;116:33-5.

76. Weisberg SP, McCann D, Desai M, Rosenbaum M, Leibel RL, Ferrante AW Jr, Obesity is associated with macrophage accumulation in adipose tissue. J Clin Invest 2003;112:1796-808.

77. Wellen KE, Hotamisligil GS. Obesity-induced inflammatory changes in adipose tissue. J Clin Invest 2003;112:1785-8.

78. Ishino K, Mutoh M, Totsuka Y, Nakagama H. Metabolic syndrome: a novel high-risk state for colorectal cancer. Cancer Lett 2013;334:56-61.

79. Bartucci M, Svensson S, Ricci-Vitiani L, Dattilo R, Biffoni M, Signore M, Ferla R, De Maria R, Surmacz E. Obesity hormone leptin induces growth and interferes with the cytotoxic effects of 5-fluorouracil in colorectal tumor stem cells. Endocr Relat Cancer 2010;17:823-33. 
80. Endo H, Hosono K, Uchiyama T, Sakai E, Sugiyama M, Takahashi H, Nakajima N, Wada K, Takeda K, Nakagama H, Nakajima A. Leptin acts as a growth factor for colorectal tumours at stages subsequent to tumour initiation in murine colon carcinogenesis. Gut 2011;60:1363-71.

81. Ekbom A, Helmick C, Zack M, Adami HO. Ulcerative colitis and colorectal cancer. A population-based study. $N$ Engl J Med 1990;323:1228-33.

82. Saleh M, Trinchieri G. Innate immune mechanisms of colitis and colitis-associated colorectal cancer. Nat Rev Immunol 2011;11:9-20.

83. Bellamkonda K, Sime W, Sjolander A. The impact of inflammatory lipid mediators on colon cancer-initiating cells. Mol Carcinog 2014 Aug 23. doi: 10.1002/mc.22207.

84. Schulz MD, Atay C, Heringer J, Romrig FK, Schwitalla S, Aydin B, Ziegler PK, Varga J, Reindl W, Pommerenke C, Salinas-Riester G, Bock A, Alpert C, Blaut M, Polson SC, Brandl L, Kirchner T, Greten FR, Polson SW, Arkan MC. High-fat-diet-mediated dysbiosis promotes intestinal carcinogenesis independently of obesity. Nature 2014;514:508-12.

85. Wu GD, Chen J, Hoffmann C, Bittinger K, Chen YY, Keilbaugh SA, Bewtra M, Knights D, Walters WA, Knight R, Sinha R, Gilroy E, Gupta K, Baldassano R, Nessel L, Li H, Bushman FD, Lewis JD. Linking long-term dietary patterns with gut microbial enterotypes. Science 2011;334:105-8.

86. Song M, Garrett WS, Chan AT. Nutrients, foods, and colorectal cancer prevention. Gastroenterology 2015;148:1244-60.e16.

87. West NJ, Clark SK, Phillips RK, Hutchinson JM, Leicester RJ, Belluzzi A, Hull MA. Eicosapentaenoic acid reduces rectal polyp number and size in familial adenomatous polyposis. Gut 2010;59:918-25

88. Calviello G, Di Nicuolo F, Gragnoli S, Piccioni E, Serini S, Maggiano N, Tringali G, Navarra P, Ranelletti FO, Palozza P. n-3 PUFAs reduce VEGF expression in human colon cancer cells modulating the COX-2/PGE2 induced ERK-1 and-2 and HIF-1alpha induction pathway. Carcinogenesis 2004;25:2303-10.

89. Calviello G, Di Nicuolo F, Serini S, Piccioni E, Boninsegna A, Maggiano N, Ranelletti FO, Palozza P. Docosahexaenoic acid enhances the susceptibility of human colorectal cancer cells to 5-fluorouracil. Cancer Chemother Pharmacol 2005;55:12-20.

90. Narayanan BA, Narayanan NK, Desai D, Pittman B, Reddy BS. Effects of a combination of docosahexaenoic acid and 1,4-phenylene bis(methylene) selenocyanate on cyclooxygenase 2, inducible nitric oxide synthase and beta-catenin pathways in colon cancer cells. Carcinogenesis 2004;25:2443-9.

91. Roynette CE, Calder PC, Dupertuis YM, Pichard C. n-3 polyunsaturated fatty acids and colon cancer prevention. Clin Nutr 2004;23:139-51.

92. Maslowski KM, Mackay CR. Diet, gut microbiota and immune responses. Nat Immunol 2011;12:5-9.

93. Oh DY, Talukdar S, Bae EJ, Imamura T, Morinaga H, Fan W, Li P, Lu WJ, Watkins SM, Olefsky JM. GPR120 is an omega-3 fatty acid receptor mediating potent anti-inflammatory and insulin-sensitizing effects. Cell 2010;142:687-98.

94. De Carlo F, Witte TR, Hardman WE, Claudio PP. Omega-3 eicosapentaenoic acid decreases CD133 colon cancer stem-like cell marker expression while increasing sensitivity to chemotherapy. PLoS One 2013;8:e69760.

95. D’Angelo L, Piazzi G, Pacilli A, Prossomariti A, Fazio C, Montanaro L, Graziani G, Fogliano V, Munarini A, Bianchi F, Belluzzi A, Bazzoli F, Ricciardiello L. A combination of eicosapentaenoic acid-free fatty acid, epigallocatechin-3-gallate and proanthocyanidins has a strong effect on mTOR signaling in colorectal cancer cells. Carcinogenesis 2014;35:2314-20.

96. Kumar S, Kumar D, Raina K, Agarwal R, Agarwal C. Functional modification of adipocytes by grape seed extract impairs their pro-tumorigenic signaling on colon cancer stem cells and the daughter cancer cells. Oncotarget 2014;5:10151-69. 